\title{
The Cytotoxic Activity of Solanum Nigrum Ethanolic Extract on Widr Human Colon Cancer Cells
}

\author{
Astrid Ayu Maruti., Ilham Augusta F., Dyaningtyas D.P. Putri, Adam Hermawan, \\ Muthi' Ikawati* \\ Cancer Chemoprevention Research Center, Faculty of Pharmacy, Universitas Gadjah Mada, Yogyakarta \\ Jalan Sekip Utara 55281 (Telp. 02746492662 Fax. 543120)
}

\begin{abstract}
Solanum nigrum L. or Leunca in Indonesia has been traditionally used as a herbal plant, which is believed to have anti-tumor properties, although the mechanism for the activity remains unknown. The resecarch aim to examine the cytotoxic effect of the ethanolic extract of Solanum nigrum on WiDr human colon cancer cells. In this study, we prepared an ethanol extract from herb of Solanum nigrum and investigated the mechanism involved in its growth-inhibitory effect on WiDr human colon cancer cells. Herbs of Solanum nigrum dry powder is extracted with $70 \%$ ethanol then added into the WiDr cell culture in 96 wells plate in various concentration : 50, 100, 250, and $500 \mu \mathrm{g} / \mathrm{ml}$. Cytotoxicity of the Solanum nigrum ethanolic extract was analyzed with MTT assay on WiDr human colon cancer cell lines. Results from the MTT assay showed WiDr cells was weakly suppressed in the presence of the extract. The result of the assay also showed a very close correlation between the Solanum nigrum extract concentration and the surviving cell numbers which means the extract caused cell death in a dose-dependent fashion in WiDr cancer cells with the IC50 of $359,23 \mu \mathrm{g} / \mathrm{ml}$. Collectively, the research suggest further studies to explore other chemopreventive possibilites of Solanum nigrum ethanolic extract
\end{abstract}

Keywords : colon cancer, MTT assay, cytotoxic, WiDr, Solanum nigrum

\section{INTRODUCTION}

Colorectal cancer is the fourth most common cancer in men and the third in women. In 2007, there are nearly 1.2 million cases of colorectal cancer found worldwide. Among those cases, about 630,000 patients are dead, accounting for $8 \%$ of all cancer deaths (ACS, 2007). The number of colorectal cancer also increases as the grow of the population (Winawer, 2007). It is important to seek for chemical compounds that can be used as chemopreventive agents against colorectal cancer.

The alternative of seeking the compund that can treat colorectal cancer is through screening medicinal herbs. One of the herb that already reported to have anticancer activity is Solanum nigrum or known as Leunca in Indonesia. Its ethanolic extract showed cytotoxic activity against MCF-7 Breast cancer cell (Ji et al., 2007). The major alkaloid compound of Leunca, solanine and solasodine also proven to be a potential anti cancer agent. It is also reported that methanolic extract of leunca showed anti- inflammatory activity against carrageenan induced paw edema (Ravi, 2009).

Based on those fact we were conducted the study of Solanum nigrum ethanolic extract (SEE) cytototoxicity effect in WiDr human colon cell. It expressed high concentration of COX-2 an inflammatory agent to induce its proliferation (Palozza et al., 2005). And its apoptosis activity went through p53 independent pathway, one of them is through the activation of p73 (Levrero et al., 2000).

\section{MATERIALS AND METHODS}

\section{Ethanolic Extract of Leunca (SEE)}

Dried powder of leunca herbs were purchased from Balai Besar Penelitian dan Pengembangan Tanaman Obat dan Obat Tradisional (B2P2TOOT), Indonesia. Determination were conducted by B2P2TOOT.

*Corresponding author e-mail : muthi_ikawati@yahoo.co.id 
Dried powder was then extracted by maceration for 5 days with $70 \%$ ethanol. Filtrate collected was concentrated using rotary evaporator (Heidolph, 2000).

\section{5-Florouracil}

5-Florouracil (5FU) was obtained from Kalbe Farma.

\section{Cell culture}

WiDr cell line was obtained from Cancer Chemoprevention research center (CCRC) laboartoty and grown in Roswell Park Memorium Institute (RPMI; Gibco) with 10\% fetal bovine serum (Gibco) and 1\% penicillin-streptomycin (Gibco) at standard culture conditions.

\section{Cytotoxicity assay}

For SEE dose-response experiments, WiDr cells were seeded in 96-well plates with $5 \mathrm{x}$ 10 cells/well and divided into control and treatment group. The cells then refreshed and cultured for 24 hours. To assess the cell viability, cells were treated with various concentration $(1$; $10 ; 50 ; 100 ; 250$; and $500 \mu \mathrm{g} / \mathrm{ml})$ of SEE dissolved in dimethyl sulfoxide (DMSO). After 24 hours of incubation culture medium was removed and cells were washed in PBS (Sigma). Then, cells were incubated with $100 \mu \mathrm{L}$ culture medium and $10 \mu \mathrm{L}$ MTT (Sigma) $5 \mathrm{mg} / \mathrm{mL}$ in each well for 4 hours. The MTT reduction reaction was stopped by $10 \%$ solution of Sodium Dodesil Sulfat (SDS) in HCl. The absorbance was measured by ELISA reader (Bio-Rad) at wave length of $595 \mathrm{~nm}$. The average cytotoxicity and the $\mathrm{IC}_{50}$ of extract were count with linear regression method by using the curve of Log concentration versus percentage of cell viability.

\section{Combination assay}

For SEE- 5FU combination, the procedure was the same as extract's cytotoxicity assay except the cells were treated with Serial dilution of SEE at $5-500 \mu \mathrm{g} / \mathrm{mL}$ was used, while $5 \mathrm{FU}$ was at 1000 nM. SEE was dissolved in as stock solutions and diluted as desired directly in the culture medium as well as $5 \mathrm{FU}$.

\section{RESULTS AND DISCUSSION}

The treatment of SEE into WiDr cells resulted the decreasing number of viable cells in dose dependent manner as seen in Fig. 1. Linear regression between concentration versus viability in percent gave the $\mathrm{IC}_{50}$ value of $359.23 \mu \mathrm{g} / \mathrm{ml}$. The value showed that the SEE does not posses a potent cytotoxic activity against WiDr. The morphology of the cell also examined and it is shown in Fig. 2. From the previous study, the $\mathrm{IC}_{50}$ value of 5-Fluorouracil against $\mathrm{WiDr}$ is $1000 \mathrm{nM}$ (Ikhtiarsyah, 2009). In order to examine the possibility of SEE to be used as co-chemotherapy agent to $5 \mathrm{FU}$, a screening conducted using the dose of $5 ; 50$, and $500 \mu \mathrm{g} / \mathrm{ml} \mathrm{SEE}$ in order to compare the effect of its high, middle, and low concentration with $1000 \mathrm{nM}\left(\mathrm{IC}_{50}\right)$ of $5 \mathrm{FU}$. The treatment yielded a non dose dependent number of cells as seen in Fig. 3.

Single treatment of SEE yielded a dose dependent manner of the decreasing of WiDr cells' viability. The treatment of SEE in low dose did not show cytotoxic activity. The number the cells even increases by 15 which indicated that there was no significant changes happen. The viability percentage decreased in a dose dependent manner as the result of treatment in higher dose: 50, 100, 250 , and $500 \mu \mathrm{g} / \mathrm{ml}$. The $\mathrm{IC}_{50}$ of SEE showed that the SEE does not posses a potent cytotoxic activity against WiDr. Although previous study using HT29 cell, the cell which WiDr derived from, showed it induced apoptosis against the cell. It maybe caused by the genetic differences between WiDr and HT-29 that leads into different mechanism of apoptosis they may through.

The further step of the study was to examine whether SEE might act as a co-chemotherapy agent in combination with $5 \mathrm{FU}$, the drug of choice in colon cancer cases. The combination treatment yielded a non-dose dependent responds. As seen in Fig. 2, there's a fluctuation in cell viability after the treatment. We interpret the data and conclude that SEE cannot be used as co-chemotherapy agent in combination with 5FU. The cell itself is very sensitive into resistance to $5 \mathrm{FU}$ due to it massive expressions of timidilat syntethase, major inhibiting target of 5-FU (Sigmond et al., 2003). 


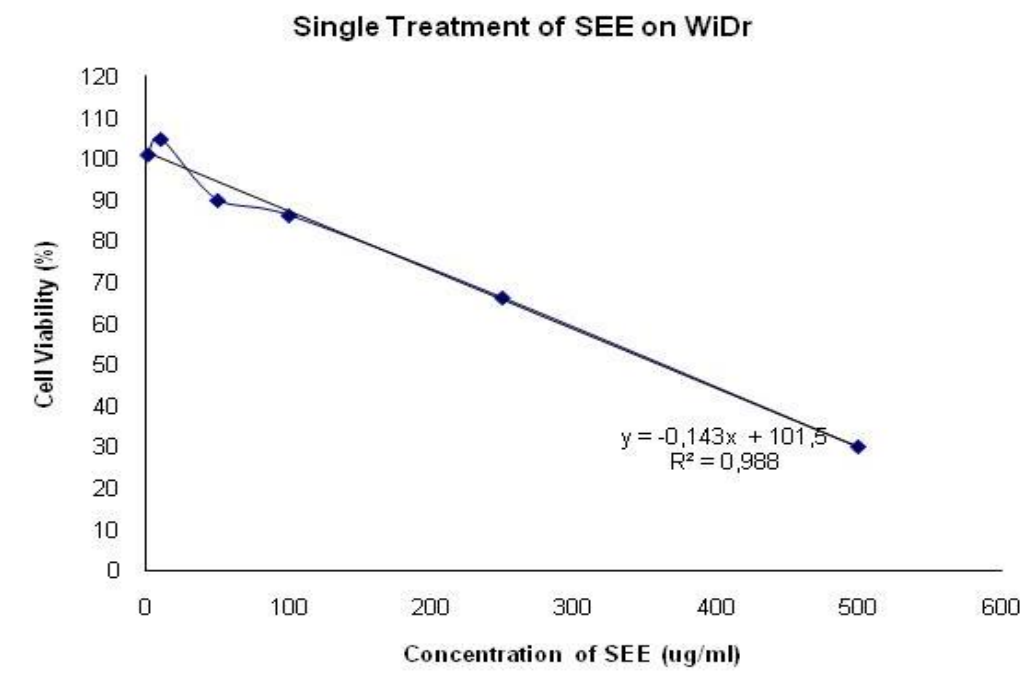

Figure I. WiDr viability after single treatment of SEE

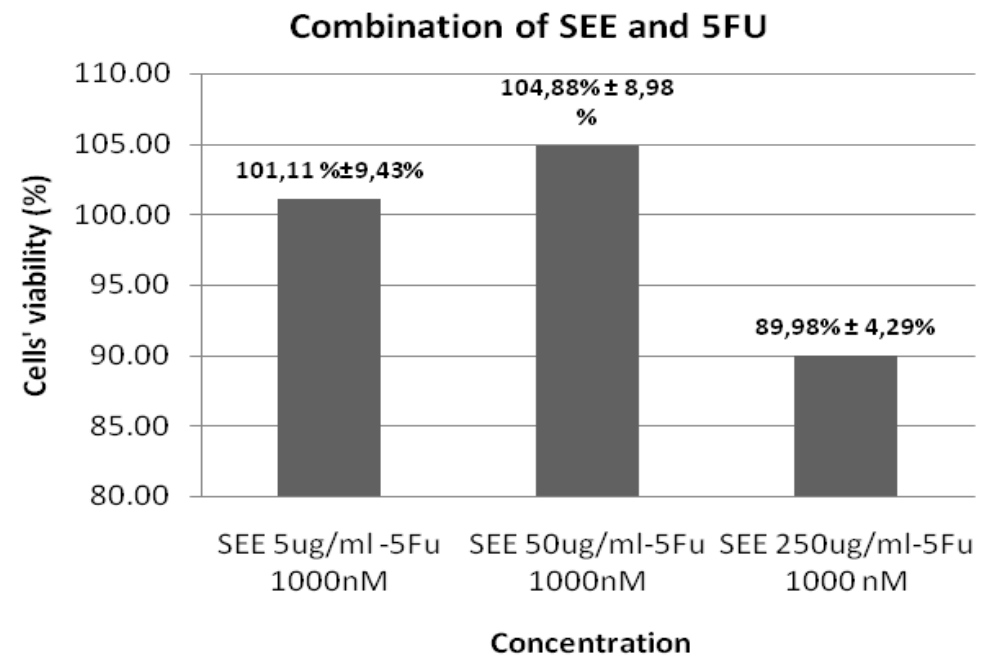

Figure 2. WiDr viability after combinational treatment of SEE and 5FU

\section{CONCLUSION}

SEE is not potent as cytotoxic agent against WiDr since it inhibits $50 \%$ of cell growth in concentration of $359.23 \mu \mathrm{g} / \mathrm{ml}$. It also decrease the ability of 5FU to inhibits the cells' growth. Further research on its molecular mechanism shall be conducted. It also proven that not all phytochemical agents are save to be used as cochemotheraphy and chemopreventive agents. Evident-based study plays an important role in the screening process.

\section{REFERENCES}

ACS, 2007, Global Cancer Facts and Figures 2007, American Cancer Society, Available at: www.cancer.org.

Chen, T.R., Drabkowski, D., Hay, R.J., Macy, M. and Peterson, W. Jr., 1987, $\mathrm{WiDr}$ is a Derivative of Another Colon Adenocarcinoma Cell Line, HT-29, Cancer Genet Cytogenet., 27(I), I25-34.

Levrero, M., Laurenzi, V. De, Constanzo, A., Sabatini, S., Gong, J., Wang, J.Y.J. and Melino, G., 2000, The p53/p63/p73 Family of Transcription Factors: Overlapping and 
Distinct Functions, Journal of Cell Science, I I3, I66I-I670.

Palozza, P., Serini, S., Maggiano, N., Giuseppe, T., Navarra, P. and Ranelletti, F.O., 2005, $\beta$ Carotene Downregulates the SteadyState, Heregulin-a-Induced COX-2 Pathways in Colon Cancer Cells, J.Nutr., 135, I29-136.

Ravi V., Saleem T.S.M., Patel S.S., Raamamurthy, J. and Gauthaman, K., 2009, AntiInflammatory Effect of Methanolic Extract of Solanum nigrum Linn Berries, International Journal of Applied Research in Natural Products, 2(2), 33-36.

Sigmond, J., Backus, H.H., Wouters, D., Temmink, O.H., Jansen, G. and Peters, G.J., 2003, Induction of Resistance to the
Multitargeted Antifolate Pemetrexed (ALIMTA) in WiDr Human Colon Cancer Cells is Associated with Thymidilate Synthase Overexpression, Biochem. Pharmacol., 66(3), 43I-8.

Son Y.O., Kim, J., Lim, J.C. and Chung. Y., 2003, Ripe fruits of Solanum nigrum L. inhibits cell growth and induces apoptosis in MCF-7 cells. Food and Chemical Toxicology, 4 I, | 42 I-| 428.

Winawer S.J., Klabunde C.N., Lanier D., Breslau E.S., Zapka J.G. and Fletcher R.H., 2007, Ransohoff D.F., J Gen Intern Med., 22(8), II95-20I5. 